\title{
回転ローラ間に生ずる接触圧力測定への 微小突起を有する電着銅薄膜の適用*
}

\author{
小 野 勇 一*1, 北岡 征一郎*1 \\ 長谷川達也*2, 松 嶋 剛 志*3
}

\section{An Application of Electrodeposited Copper Foil with Micro Projections to the Measurement of Pressure between Two Rollers in Contact}

Yuichi ONO*4, Seiichiro KITAOKA, Tatsuya HASEGAWA and Takeshi MATSUSHIMA

\footnotetext{
${ }^{* 4}$ Department of Mechanical Engineering, Tottori University,

4-101 Koyama-cho Minami, Tottori-shi, Tottori, 680-8552 Japan
}

\begin{abstract}
An electrodeposited copper foil that possesses conical projections regularly is applied to measure the pressure between two rollers in contact. Before measuring the pressure, the effects of number of cycles and frequency of the pressure on the ratio of real contact surface area to bottom area of the projections are investigated using servohydraulic testing machine. The cyclic softening of the copper foil is gradually recognized after $10^{3}$ cycles and its frequency dependence is also recognized in the pulsating compression test. Namely, if the number of cycles is the same, the increase of the frequency delays the progress of cyclic softening. However, if the number of cycles is $10^{2}$ cycles in which the cyclic softening hardly proceeds, the ratio of real contact surface area to bottom area of the projections doesn't depend on the frequency, and the ratio is almost same value in the static test. The pressure between two rollers is measured at $10^{2}$ cycles. The mean pressure over the width direction of the roller obtained by this method is in good agreement with theoretical values obtained by load cell.
\end{abstract}

Key Words: Experimental Stress Analysis, Contact Problem, Fatigue, Plasticity

\section{1. 緒言}

機械要素間の接触面に生ずる圧力を実験的に測定す るためには, 感圧フィルム法, 圧電セラミックスを用 いた方法 ${ }^{(1)}$ ，および光弾性法などがある. しかしな がら，感圧フィルム法では，測定は簡便であるが，機 械要素間にしばしば生ずる高い圧力の計測ができない. また，圧電セラミックスを用いた方法では，高圧の測 定は可能であるが，センサ部が複雑で大きくなるとと もに，機械要素の疲労の原因となる局所的な圧力を計 測するには十分とはいえない.このように，実験的圧 力測定法には一長一短があり, また繰返し圧力を計測 できる測定法も少ない. そこで，これらの測定原理と は異なる微小突起を有する電着銅薄膜を用いた圧力測 定法 (2) (3) が提案されている. この測定法は, 固体接 触面の微小領域に生ずる静圧や繰返し圧力の測定を目 的とした計測法である.すなわち，電着により作製し

* 原稿受付 2006 年 6 月 29 日

*1 正員, 鳥取大学工学部(画 680-8552 鳥取市湖山町南 4-101).

*2 正員, 中日本自動車短期大学 (拜 505-0077 岐阜県加茂郡坂祝 町深萱 1301)

*3 学生員, 鳥取大学大学院工学研究科

E-mail : ono@mech.tottori-u.ac.jp
た多数の微小な突起を有する銅薄膜を固体接触面に挿 入し, 突起部先端が静圧や繰返し圧力の作用により塑 性変形し, 固体と突起との真実接触面積がこれらの圧 力に依存する点に着目した方法である。したがって, 予め較正試験により，圧力と真実接触面との関係を求 めておけば，機械要素間に生ずる圧力の測定が可能と なる．また，薄膜に銅よりもさらに硬さの大きい金属 薄膜を用いれば，高圧測定の可能性も期待できる.

ところで，機械要素などに用いられる回転するロー ラでは，その接触面に周期的に局所的な圧力が生じ, 高圧力になる場合も少なくない. したがって，このよ うな圧力を実測することは，ローラの磨耗や疲労を検 討するうえでも重要な課題といえる.

以上の観点から本報告では, 微小突起を有する電着 銅薄膜を用いて回転するローラ間に生ずる圧力測定の 可能性を検討した，すなわち，まず油圧制御式疲労試 験機を用いて, 微小突起を有する電着銅薄膜の繰返し 圧縮試験を種々の圧力振幅と周波数のもとで実施し, 静圧試験により得られた結果と比較した. 次いで，こ の結果に基づいて，自作したローラ試験機の接触面に 生ずる繰返し圧力を計測し，得られた結果を接触問題 の弾性解と比較し, 本測定法の妥当性を検討した. 


\section{2. 実験方法}

\section{$2 \cdot 1$ 微小突起を有する電着銅薄膜の作製 図 1}

に示すように，メタルプリンタを用いて，鏡面仕上げ を施したステンレス板の $70 \mathrm{~mm} \times 70 \mathrm{~mm}$ の領域に微小な 円錐状の圧痕を規則的に作製した，圧痕の直径は約 $75 \mu \mathrm{m}$ であり，圧痕の間隔は約 $100 \mu \mathrm{m}$ である. このス テンレス板をめっき基板とし，硫酸銅を主体とするめ つき液 ${ }^{(4)} に て$ 銅めっきを施した，めっき終了後，最 終電着面にはステンレス板の圧痕に沿って凹部が残る ため, これを耐水研磨紙にて除去して平滑面とした後, 基板からめっき部を剥離し，微小突起を有する電着銅 薄膜とした．図 2 には，作製した銅薄膜のレーザ顕微 鏡写真を示す，突起部の高さは, 約 $28 \mu \mathrm{m}$ であり, 薄 膜の厚さ（突起先端部から研磨面までの厚さ）は約 $65 \mu \mathrm{m}$ である.

$2 \cdot 2$ 静圧試験 図3に示寸圧力負荷ジグを MTS 材料試験機に装着し，上下型の凸部にこれと同一直径 に切出した微小突起を有する電着銅薄膜を挟みこみ, 種々の静圧 $p_{s}$ を $60 \mathrm{~s}$ 加えて試験を実施した. 静圧負荷 後, 図 4 に示寸ように, 光学䫓微鏡に備え付けられた デジタルカメラにて突起の画像を取り込み，圧力負荷 ジグとの真実接触面となる突起部先端の平坦部の面積 (真実接触面積) $A_{r}$ と突起の底面積 $A$ を画像処理ソフ トにより計測し， $A_{r} / A$ を求めた。ここで， $A_{r} / A$ は薄膜

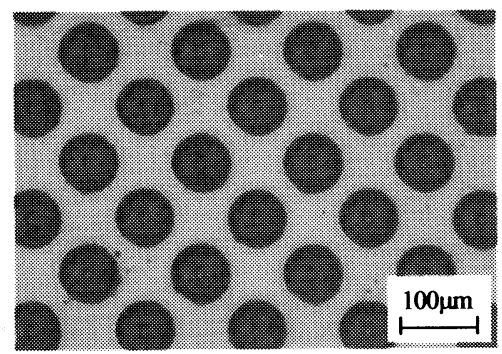

Fig. 1 Stainless steel plate with micro indentations

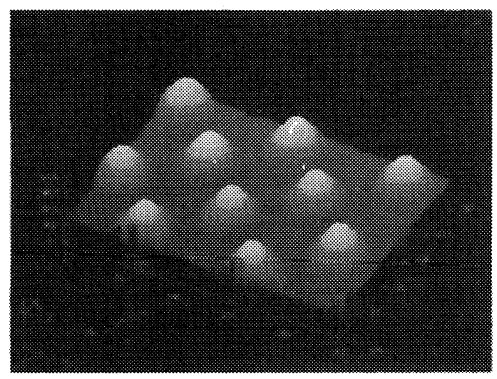

Fig. 2 Electrodeposited copper foil with micro projections
の任意の 8 ケ所に対して得られた画像における合計 30 個の突起について計測した.

$2 \cdot 3$ 繰返し圧力試験＼cjkstart幅 $w$ の円柱が接触した 場合, 接触面には図 5 に示すような圧力が分布する ${ }^{(5)}$. なお，図中の $2 a$ は接触面の円周方向の幅である.ここ で，円柱の外周における任意の一点に着目すれば，円 柱が 1 回転することにより円柱同士の接触面で図 5 に 示すような圧力が生ずるので， 1 回転毎に図 6 の実線

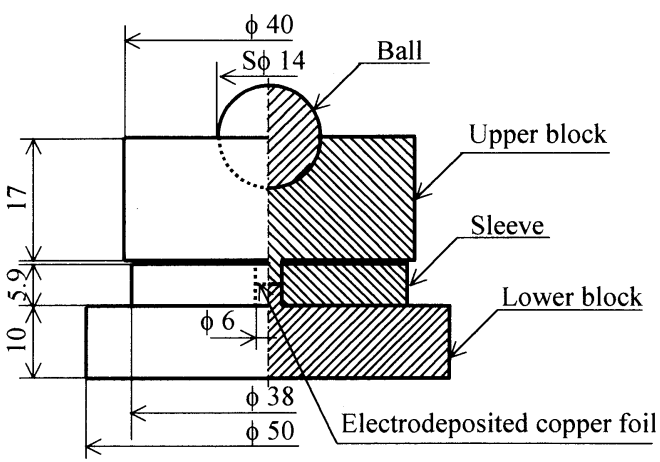

Fig. 3 Apparatus for static and dynamic calibration test

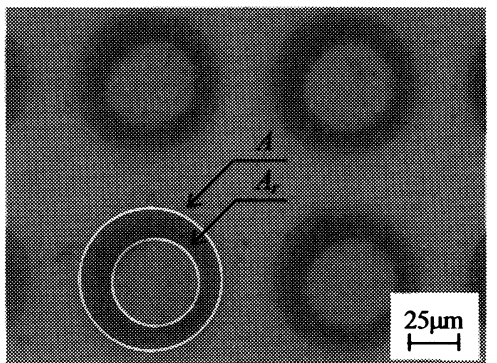

Fig. 4 Configuration of micro projections deformed by static pressure $\left(p_{s}=100 \mathrm{MPa}\right)$

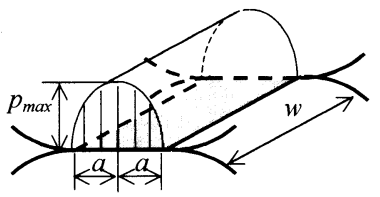

Fig. 5 Contact pressure between two cylinders

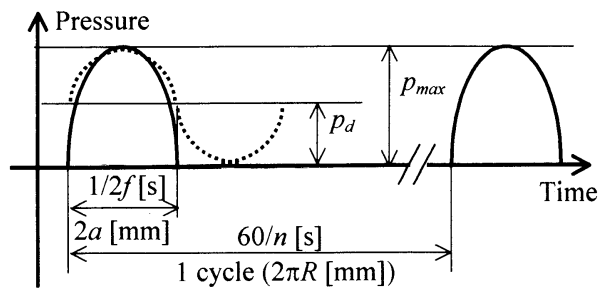

Fig. 6 Pressure pattern of rolling cylinder 
Table 1 Experimental condition of dynamic test

\begin{tabular}{c|c|c|c}
\hline \hline$f[\mathrm{~Hz}]$ & 1 & 10 & 100 \\
\hline \multirow{4}{*}{$N$ [cycle] } & 10 & & \\
\cline { 2 - 4 } & $10^{2}$ & $10^{2}$ & \\
\cline { 2 - 4 } & $10^{3}$ & $10^{3}$ & $10^{3}$ \\
\cline { 2 - 4 } & $10^{4}$ & $10^{4}$ & $10^{4}$ \\
\cline { 2 - 4 } & & $10^{5}$ & $10^{5}$ \\
\cline { 2 - 4 } & & & $10^{6}$ \\
\hline
\end{tabular}

で示すような分布の圧力が生ずることになる.ここで， $n$ はローラの回転数[rpm]である.これと同じ圧力波形 をMTS 材料試験機では再現できないため, 図中に破線 で示したような圧力振幅 $p_{d}$ の正弦波形（周波数 $f$ ) でこれを近似し，前節の静圧試験と同様の圧力負荷ジ グを用いて, 表 1 に示寸種々の周波数 $f$ と繰返し数 $N$ において片振り圧縮試験を実施した。 なお, 最大圧力 $p_{\text {max }}\left(=2 p_{d}\right)$ は, $50,100,150 \mathrm{MPa}$ とした.

$2 \cdot 4$ ロ一ラ試験 図7(a), (b)には, 自作した口 一ラ試験機を, 図 8 にはローラの形状・寸法を示寸.

$\mathrm{AC}$ モータの回転が，ギア比 1 の平歯車を介して上下 ローラに伝わる構造となっている. クロスヘッドに取 り付けられた六角ボルトを緩めることにより，上ロー ラがガイドに沿って徐々に下降し，下ローラに接触す る.さらに六角ボルトを緩めれば，下ローラにクロス ヘッドの荷重が負荷される. ローラの接触面には精密 研磨が施してあり，ローラの接触幅 $w$ をそれぞれ $2.5 \mathrm{~mm} ， 5.0 \mathrm{~mm}$ として試験を実施した。なお，ローラ

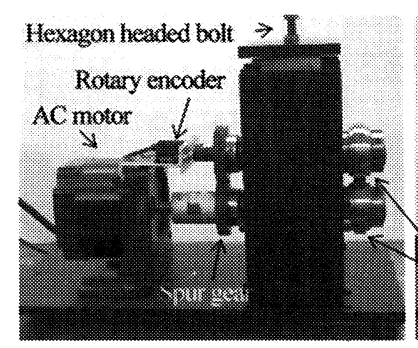

(a) Side view



(b) Front view
Fig. 7 Roller testing machine

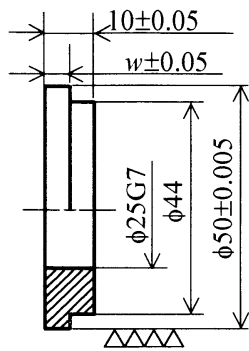

Fig. 8 Geometry and dimensions of test roller
の材質は SNCM439（ヤング率 $E=204 \mathrm{GPa}$ ，ポアソン 比 $v=0.3$ ）である. おおよそ $10 \mathrm{~mm} \times 10 \mathrm{~mm}$ に切出した 微小突起を有する電着銅薄膜の両端を粘着テープでロ 一ラに固定し，ローラ間に生ずる圧力を上述の較正試 験の結果から求めた。 また，ロードセルにより，上下 ローラ間に作用する荷重を計測し, 接触問題の弾性解 から得られる接触圧力を求め, その妥当性を検証した。

\section{3. 実験結果および考察}

$3 \cdot 1$ 静圧試験 図 9 には, 静圧圾験により得られ た $A_{r} / A$ と $p_{s}$ との関係を示す,なお, 突起の底面積 $A$ は, 突起先端の塑性変形量が小さいときはほとんど変化し ないが，塑性変形量が大きくなると $A$ も増加すること が確認できた. 図から， $p_{s}$ の増加とともに $A_{r} / A$ も増加 し, 上に凸の曲線となることから, 静圧の増加ととも に加工硬化が進行する ${ }^{(2)}$. また, この薄膜では, 最 大で $300 \mathrm{MPa}$ 程度の静圧測定が可能となる. 両者の関 係を最小二乗法により 2 次近似し, 次式とおく.

$$
A_{r} / A=s p_{s}^{2}+t p_{s}
$$

ここで， $s, t$ は定数であり，それぞれ $s=-4.39 \times 10^{-6}$, $t=3.48 \times 10^{-3}$ となる.

$3 \cdot 2$ 綝返し圧力試験 図 10(a) (c)kは, それぞ れの周波数 $f$ において得られた $A_{r} / A$ と繰返し数 $N$ との 関係を片対数紙により示す. 図には, $p_{\text {max }}=p_{s}$ として静 圧試験の結果を直線（実線，破線）により表示した. 図から, $f=1 \mathrm{~Hz}$ の場合, $N$ が $10^{2}$ 回以下では, $A r / A$ は 静圧試験の結果とほぼ一致する. また, $f=10 \mathrm{~Hz}, 100 \mathrm{~Hz}$ の場合に関しても，実験值から推定して $N$ が $10^{2}$ 回以 下では， $A / A$ は静圧試験結果と一致するものと考えら れる. しかしながら, $N$ が $10^{2}$ 回を超えると, $N$ の増加 とともに $A_{r} / A$ も増加し, 冷間加工された銅に認められ

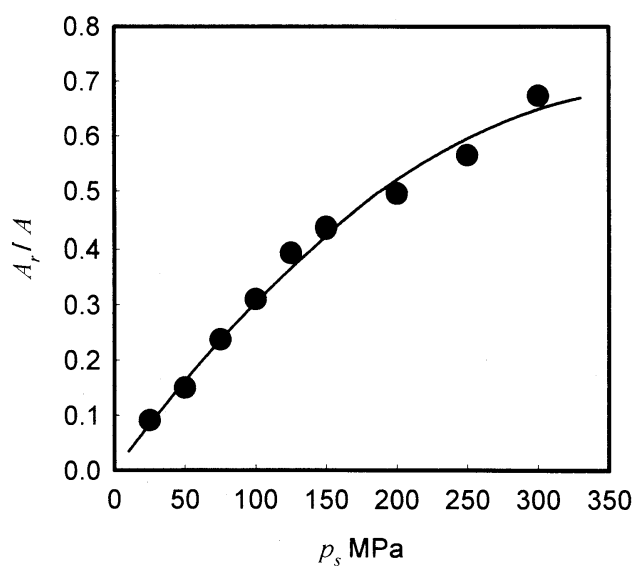

Fig. 9 Relationship between $A_{r} / A$ and $p_{s}$ 
るような加工軟化 ${ }^{(6)}$ が進行していくことがわかる.

図 11(a)〜(c)には, $N=10^{2}, 10^{3}, 10^{4}$ における $A_{r} / A$ と 周波数 $f$ との関係を片対数紙により示守. 図には図 10

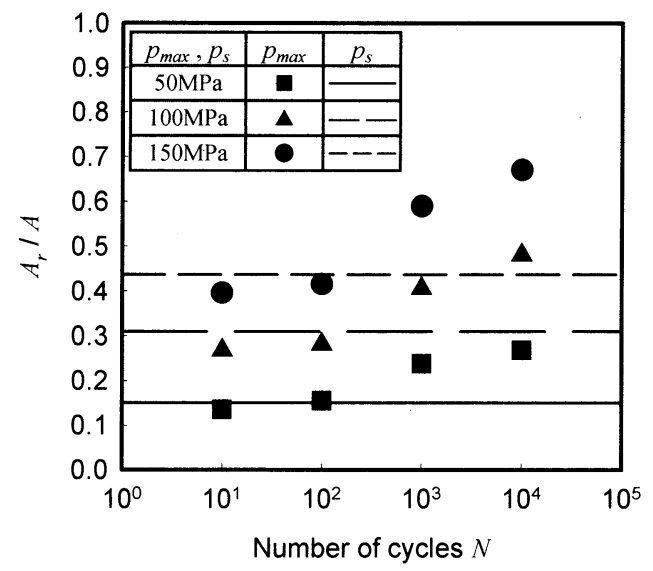

(a) $f=1 \mathrm{~Hz}$

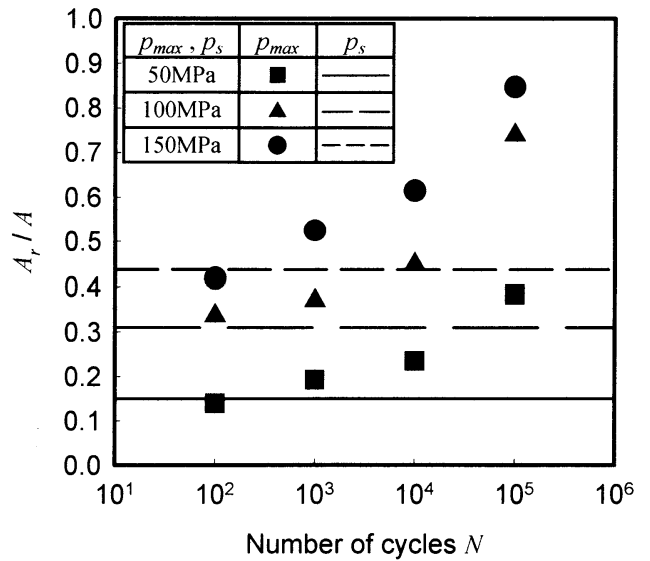

(b) $f=10 \mathrm{~Hz}$

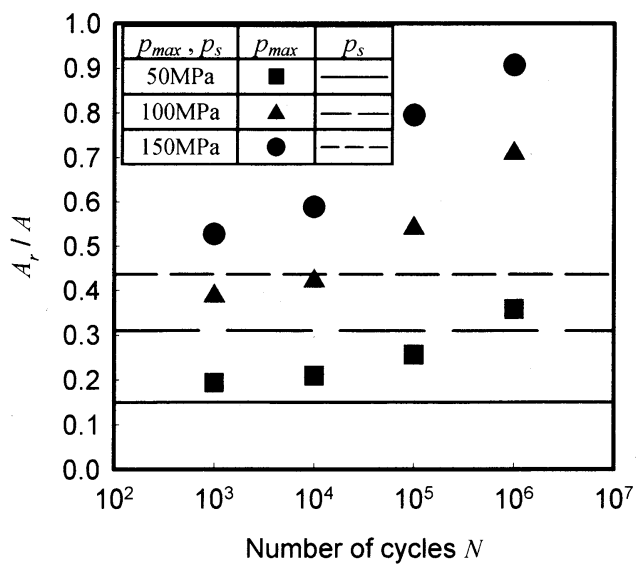

(c) $f=100 \mathrm{~Hz}$

Fig. 10 Relationship between $A_{r} / A$ and $N$
と同様に静圧試験結果を直線で表示した. 図 11(a)より, 加工軟化が顕著に進行しない $N=10^{2}$ 回における $A_{r} / A$ は周波数に依存しないが，図 11(b)，(c)のように軟化の

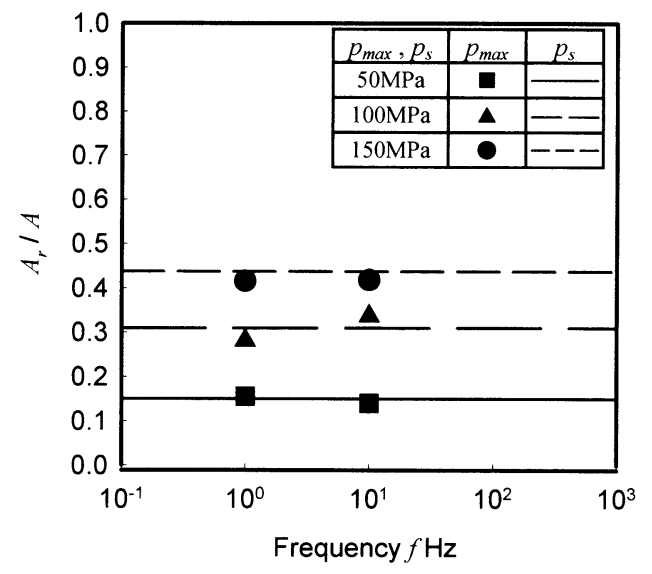

(a) $N=10^{2}$ cycle

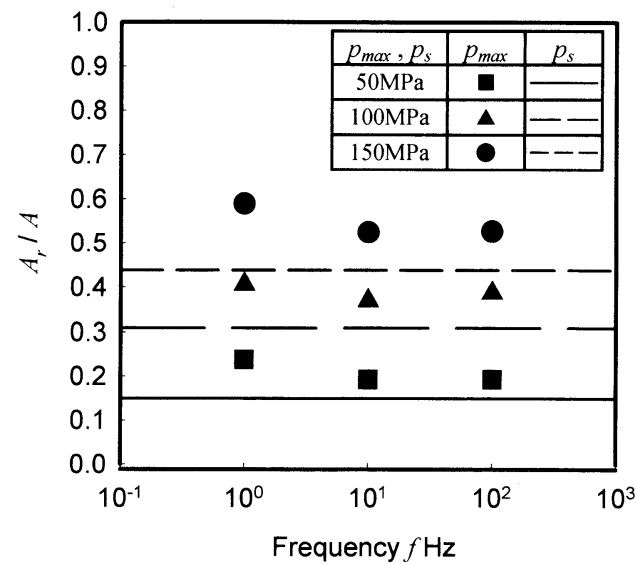

(b) $N=10^{3}$ cycle

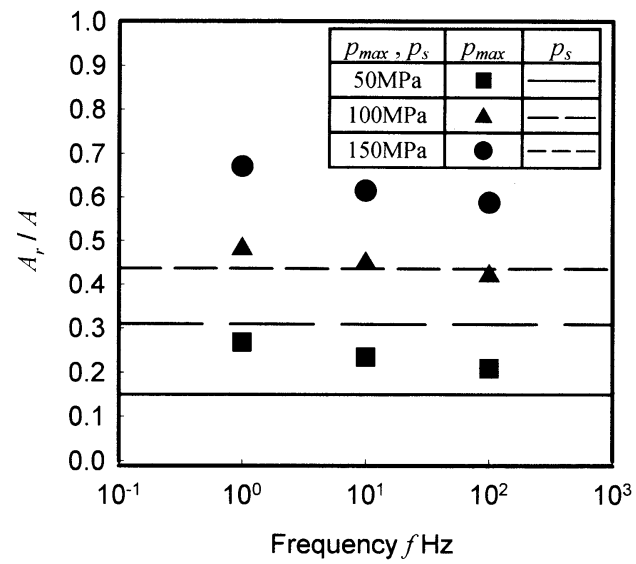

(c) $N=10^{4}$ cycle

Fig. 11 Relationship between $A_{r} / A$ and $f$ 
進行とともに $A / A$ の $f$ 依存性が認められ, $f$ の増加とと もに $A_{r} / A$ 以小さくなる傾向が認められる. この要因に ついて考察すると以下のようになる。一般に軟鋼など の降伏点にはひずみ速度依存性があることが知られて おり,ひずみ速度の増加とともに降伏点も上昇する ${ }^{(7)}$. このようなひずみ速度依存性は電着により作製した銅 薄膜にも認められている ${ }^{(8)}$ ので, 本実験においても $N$ が小さい場合では, 周波数の増加とともに $A_{r} / A$ も小さ くなるものと考えられる. しかしながら, 図11(a)に認 められるように, 加工軟化がほとんど進行しない $N$ が 小さい場合での $A_{r} / A$ の周波数依存性はほとんど認めら れないことから，上述の降伏点のひずみ速度依存性が $A_{r} / A$ に及ぼす影響は軽微であると考えられる。一方, $N$ が一定の場合, $f$ の増加とともに圧力の作用時間は短 くなる. 加工軟化は転位が安定な状態に移動すること により生ずるため ${ }^{(9)}$, 圧力の作用時間が減少すれば, この移動に要する時間が十分ではなくなるため, 軟化 の進行が遅れ, 図11 に認められるような結果になった ものと考えられる．したがって，銅薄膜の繰返し軟化 が進行する $N$ において本測定法を適用するには, 上述 の $A_{r} / A$ の加工軟化の程度とその $f$ 依存性を考慮する必 要がある.

$3 \cdot 3$ 口ーラ試験 図7において, 上下ローラが接 触した位置を基準として下ローラを取り外し, ここへ ロードセルを挿入して，5回の計測によりクロスヘッ ドの荷重 $W$ を求めれば, $W=49.2 \pm 2.4 \mathrm{~N}$ となった. こ れに基づいて，ローラに作用する荷重の周波数を見積 ってみた. 図 5 に示すように接触面の半幅を $a$ とすれ ば, 弾性理論により, 上下ローラの弾性係数 $E, v$, お よび半径 $R$ が等しいとき， $a$ は次式で表される ${ }^{(10)}$.

$$
a=\sqrt{4 \vartheta P R}
$$

ただし，

$$
\vartheta=\left(1-v^{2}\right) / \pi E
$$

であり, $P$ はローラの単位幅あたりの荷重 $(=W / w)$ を表す. また, 図6の関係から次式が成立する.

$$
2 a: 2 \pi R=\frac{1}{2 f}: \frac{60}{n}
$$

したがって，較正試験の周波数 $f$ は次式となる.

$$
f=\pi n R / 120 a
$$

$n=100 \mathrm{rpm}$ ，ローラの幅 $w$ が $2.5 \mathrm{~mm}, 5.0 \mathrm{~mm}$ の場合, $f$ を式 (2) 〜 (5) を用いて求めると, それぞれ $1240 \mathrm{~Hz}$, $1750 \mathrm{~Hz}$ となる. 本実験で用いた材料試験機では, この
ような高い周波数のもとで繰返し圧力試験を実施する ことはできない，また，上述の方法により圧力の周波 数を求めるには, ローラに作用する荷重を予め求めて おく必要がある.このような場合には, 実験的圧力測 定法によらなくても，後述するような弾性解を用いる ことでローラの幅方向に作用する接触圧力の平均值を 見積ることができる，しかしながら，実際には，ロー ラに作用する荷重が未知である場合が多いため, 接触 圧力の計測が必要となる.このような場合には, 上述 のように周波数を求めることはできない，そこで, 前 節の結果から加工軟化が顕著に表れない繰返し数であ れば, $A_{r} / A$ の周波数依存性もほとんどなく, 静圧試験 結果を利用できると考えられることから $N=10^{2}$ 回と 設定して，ローラ試験を実施した。

図 12(a), (b)にはそれぞれローラ幅が $2.5 \mathrm{~mm}, 5 \mathrm{~mm}$ の場合に得られたローラの幅方向の圧力分布を示寸. ここで, $A_{r} / A$ の計測は, ローラの幅方向に 3 箇所実施

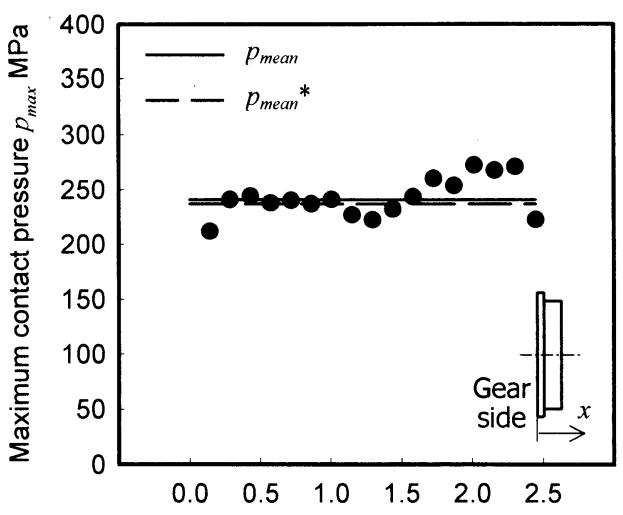

Distance from inner contact point $x \mathrm{~mm}$ (a) $w=2.5 \mathrm{~mm}$

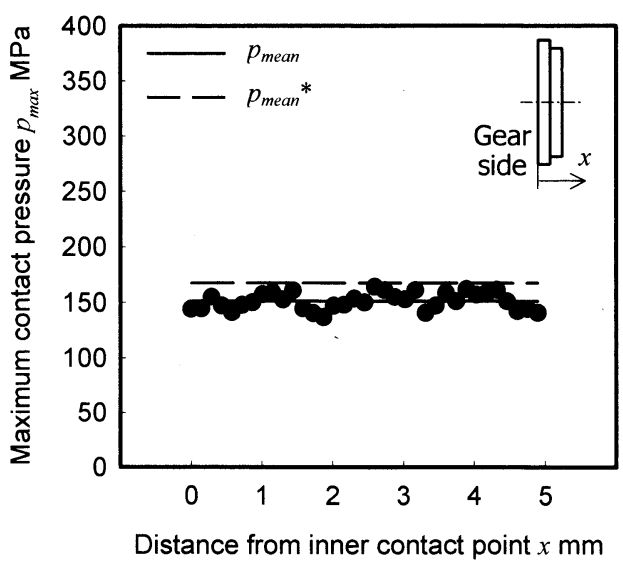

(b) $w=5.0 \mathrm{~mm}$

Fig. 12 Pressure distribution to the width direction of a roller 
Table 2 Coefficients of approximate equations

\begin{tabular}{c|c|c}
\hline \hline$w[\mathrm{~mm}]$ & 2.5 & 5.0 \\
\hline$h$ & -78.469 & -0.7382 \\
\hline$i$ & 394.16 & 6.4753 \\
\hline$j$ & -643.46 & -18.102 \\
\hline$k$ & 388.91 & 19.189 \\
\hline$l$ & 168.77 & 143.94 \\
\hline
\end{tabular}

Table 3 Comparison of mean pressure obtained by copper foil and load cell

\begin{tabular}{c|c|c}
\hline$w[\mathrm{~mm}]$ & Copper foil & Load cell \\
\hline 2.5 & 241 & $237 \pm 6$ \\
\hline 5.0 & 153 & $168 \pm 4$ \\
\hline
\end{tabular}

し，その平均值を採用した。また， $A_{r} / A$ と $p_{\max }$ との関 係には静圧試験に対して得られた式 (1) の関係式を用 いた. 図から, ローラ幅が小さくなると， $p_{\max }$ も明ら かに大きくなる.

得られた結果を弾性解と比較し，その妥当性を検証 してみた. 図 12 の実験值を最小二乗法により 4 次近似 L, 次式とおく.

$$
p_{\max }=h x^{4}+i x^{3}+j x^{2}+k x+l
$$

ここで， $h, i, j, k, l$ は定数であり，その值を表 2 に 示す.これより, ローラ幅方向の圧力分布の平均值 $p_{\text {mean }}$ は次式で表される.

$$
p_{\text {mean }}=\frac{\int_{0}^{w} p_{\max } d x}{w}
$$

これにより得られる値を図 12 に実線で示す.また，弾 性理論により，ローラの接触面に作用する圧力 $p_{\text {mean }}{ }^{*}$ は, 次式で表される ${ }^{(10)}$.

$$
p_{\text {mean }} *=\frac{1}{\pi} \sqrt{\frac{P}{\vartheta R}}
$$

ロードセルにより得られた荷重 $W$ から, 式(8)により $p_{\text {mean }}$ *を求めれば, 図 12 の破線となる. 表 3 にはこれ らの值を比較して示す. 図 12 と表 3 より, 両者は良好 な一致を示し，ロードセルにより得られた值を真值と した場合の相対誤差は，それぞれ $w=2.5 \mathrm{~mm}$ の場合で $2 \%, w=5.0 \mathrm{~mm}$ の場合で $9 \%$ となる.

したがって，加工軟化が顕著に現れない繰返し数で は，接触圧力の周波数によらず，本手法によりローラ の接触面に作用する圧力分布を計測できるといえる.

\section{4. 結 言}

回転するローラ間の圧力測定に対し，微小突起を有 する電着銅薄膜による接触圧力計測法の適用の可否を
検討するため，まず，種々の周波数と繰返し数のもと で片振り圧縮試験を実施し，静圧試験による結果と比 較した。ささらにこの結果を利用して回転するローラ 間に生ずる圧力測定を実施した.

得られた結果を要約すれば，以下のようになる.

（1）突起部先端の真実接触面積と突起の底面積との 比 $A_{r} / A$ は繰返し数 $N$ が $10^{2}$ 回以下では，静圧試験の結 果とほぼ一致する.

（2） $N$ が $10^{2}$ 回を超えると， $N$ の増加とともに $A_{r} / A$ も増加し, 加工軟化が進行していく.

(3) 加工軟化が顕著に進行しない $N=10^{2}$ 回における $A_{r} / A$ は周波数 $f$ に依存しない.

（4）加工軟化の進行とともに $A_{r} / A$ の $f$ 依存性が認め られ，同一の $N$ に対する $A_{r} / A$ は $f$ 増加とともに小さ くなる傾向にある.

（5）本手法により回転するローラ間に生ずる繰返し 圧力を計測すれば，弾性解とよく一致する.

\section{文献}

(1) Oda, J. et al., Development of Sensing System of Piezoelectric Ceramics Measuring Contact Pressure Distributions, Transactions of the Japan Society of Mechanical Engineers, Series A, Vol. 54, No.498 (1988), pp. 399-404.

(2) Kitaoka, S. et al., Measurement of Contact Pressure by Electrodeposited Copper Foil (2nd Report, Measurement of Static Pressure by the Foil with Micro Projections), Transactions of the Japan Society of Mechanical Engineers, Series A, Vol. 64, No.619 (1998), pp. 689-695.

(3) Kitaoka, S. et al., Measurement of Contact Pressure by Electrodeposited Copper Foil (3rd Report, Evaluation of Cyclic Pressure by the Foil with Micro Projections), Transactions of the Japan Society of Mechanical Engineers, Series A, Vol. 68, No.670 (2002), pp. 930-935.

(4) Ohkubo, H., Copper Electroplating Method of Stress Analysis, Memoirs Fac. Eng. Nagoya Univ., Vol. 20, No.1 (1968), pp.1.

(5) Kawata, Y. et al., A Handbook of Materials Strength (in Japanese), (1966), p.247, Asakurashoten.

(6) Ralph I. S., Ali F., Robert R. S., and Henry O. F. Metal Fatigue in Engineering, (2001), p. 100, A Wiley-Interscience Publication.

(7) Yokobori, T., Strength, Fracture and Fatigue of Materials (in Japanese), 3rd Ed., (1993), p.38, Gihodoshuppan.

(8) Kitaoka, S. et al., Measurement of Biaxial Stress using Electrodeposited Copper Foil with a Microcircular Hole (Effect of Frequency and Wave Form on Strain Sensitivity), Transactions of the Japan Society of Mechanical Engineers, Series A, Vol. 70, No.694 (2004), pp. 837-841.

(9) Ralph I. S., Ali F., Robert R. S., and Henry O. F., Metal Fatigue in Engineering, (2001), p. 43, A Wiley-Interscience Publication.

(10) Timoshenko, S. P. and Goodier, J. N., Theory of Elasticity, 3rd Ed., (1970), p.418, McGraw-Hill. 